\title{
Rachel Carson: Saint or Sinner?
}

\author{
Mark Hamilton Lytle' \\ Departments of History and Environmental and Urban Studies \\ Bard College, Annandale-on-Hudson, United States
}

Those who honored Rachel Carson after her death in 1964 knew how hard she had struggled to warn against human abuse of the Earth. In memory of her heroic efforts and her inspiring prose, they initiated a process that one scholar compared to a "secular canonization," inspired by a vision of "Saint Rachel of the Silent Spring" (Howarth, 2005, p. 42). That view did not go long unchallenged. A range of conservatives associated Carson with the two 'isms' of the 1960s that galled them most: feminism and environmentalism. They seemed unaware that Carson resisted efforts to link her to the feminists, preferring to stress her reputation as a writer and scientist. All the same, she was unabashedly proud of her contributions to the popularity of environmentalism and the science of ecology. ${ }^{2}$

Conservatives were headed in the opposite direction. Richard Nixon's dalliance with environmentalists, despite his Machiavellian motives, deepened their long-held suspicions. With the election of Ronald Reagan in 1980, conservatives launched a powerful counterattack against the political and cultural legacy of the 1960s. One of their primary targets was the environmental movement and the regulatory apparatus that it promoted. Economic conservatives and libertarians, who resented government regulations and were eager to limit the size and power of government, chafed at the host of laws and agencies created to improve the quality of air and water, save wilderness, protect endangered species, and limit pollution. Many business leaders charged that environmental red tape hamstrung the nation's ability to compete against foreign manufacturers; libertarians argued that regulation denied private citizens their right to exploit public resources. ${ }^{3}$

Embracing both views, Reagan's Secretary of the Interior, James Watt, maintained that "failure to know our potential, to inventory our resources, intentionally forbidding proper access to needed resources, limits this nation, dooms us to shortages and damages our right as a people to dream heroic dreams" (Shabecoff, 1993, p. 204).

\footnotetext{
1 Author contact: lytle@bard.edu

2 Among the Rachel Carson biographies, see Linda Lear, Rachel Carson: Witness for Nature (2009) and William Souder, On a Farther Shore: The Life and Legacy of Rachel Carson, Author of Silent Spring (2013). Much of the material in this article comes from Mark Hamilton Lytle, The Gentle Subversive: Rachel Carson, Silent Spring, and the Rise of the Environmental Movement (2007a).

3 A good source for the growing anti-environmental movement is David Helvarg, The War Against the Greens (1994). See also Phillio Shabecoff, A Fierce Green Fire: The American Environmental Movement (1993) and Robert Gotlieb, Forcing the Spring: The Transformation of the American Environmental Movement (1993).
} 
With missionary zeal, Watt set about reordering the nation's priorities: opening vast areas to mining and oil drilling, refusing to enforce environmental rules and regulations, turning national parks over to private concessionaires, and selling off public lands. In time, Watt's zeal turned him into a political liability and forced his resignation in 1983. He was not, however, a lone voice crying against wilderness, but rather an outspoken representative of what came to be known as the "Sagebrush Rebellion" and, more generally, the "Wise Use" movement. These conservative rebels were determined to free property owners from environmental regulation and argued that transferring government-controlled resources into private hands would promote economic growth (Helvarg, 1994; Shabecoff, 1993).

To their dismay, Reagan's Wise Use allies discovered that the public remained loyal to the values Rachel Carson promoted. Most Americans did not want to abandon environmental rules and favored the clean-up of the nation's air and water. Thus, the Reagan revolt against environmentalism proved stillborn. Efforts to dismantle the Environmental Protection Agency (EPA) did not simply die, however, nor did the Wise Use rebels fold their tents and head for high ground. In 1994, they were back in action as Congressman Newt Gingrich of Georgia helped Republicans win control of both the house of representatives and the senate. The centerpiece of their broad agenda to limit government and restore "family values" was a plan to reduce environmental regulation.

The EPA once again lay in their sights. Congressman Tom DeLay of Texas called their plan for deregulation "Project Relief." As a former exterminator, DeLay knew something of the restrictions imposed by environmental rules. He boldly announced to the press, "You've got to understand, we are ideologues. We have an agenda. We have a philosophy. I want to repeal the Clean Air Act" (Hacker \& Pierson, 2005, p. 142). One moderate Republican senator, dismayed at the boldness of DeLay's plan to revise environmental law, called it "terrible legislation. When all the artichoke leaves are peeled away, they are out for the Clean Air Act, the Clean Water Act, the Endangered Species Act; that is what they are gunning for" (Hacker \& Pierson, 2005, p. 142).

In their zeal to destroy the environmental movement, conservatives trained their fire on Rachel Carson. How better to discredit the movement than by tarnishing the reputation of its patron saint? In many ways, their tactics differed little from those used in the 1960 s by critics of Silent Spring. Carson, they charged, had practiced bad science and thereby misrepresented the value of DDT. More than that, the reverence for nature she encouraged created formidable roadblocks to the rapid exploitation of natural resources they advocated.

Political scientist Charles Rubin launched an early attack to discredit Carson's science, though his primary target was the "Green Crusade" to protect the environment, and not simply Carson. Rubin (1994) agreed with Paul Brook's assessment that 
Silent Spring was "one of those rare books that change the course of history ... by altering the direction of man's thinking" (pp. 30-31). Given what he saw as the shoddiness of her research, how then to account for its enormous significance, Rubin wondered. Was it her literary skill? Rubin thought not, since he believed nature writing was a well-established genre before Carson began to publish. Was it her warning against pesticides? No, others had done so before her and nothing in her research for Silent Spring was original. "Was it her fanatical attacks on DDT and modern chemical technology that set the tone for the subsequent excesses of environmental fear-mongering?" he asked, expecting no answer (Rubin, 1994, pp. 30-31).

Rubin did make a persuasive case that Carson was not always neutral in her use of sources and that she was sometimes driven by moral fervor more than by scientific evidence. Indeed, her use of evidence was selective, and she made no attempt to catalogue the benefits of pesticides, as critics such as Rubin insisted she should have. But there was no need to. The chemical giants required little defending. They had at their disposal vast public relations and advertising resources and spent millions extolling the virtues of pesticides without ever acknowledging their toxicity. Carson provided information that neither the companies nor the government had ever made public but that she believed people had both a need and a right to know.

Such attacks against Carson suggest her critics had a bigger target in mind. Writing in 1995, after the fall of the Berlin Wall and the collapse of communism, Rubin believed that Carson's disciples in the environmental movement-those he dismissed as "utopian reformers"-posed a new threat to freedom and liberty. He suspected that "as 'red' totalitarianism declines, the aspirations of our radical reformers may become increasingly 'green' " (Rubin, 1994, pp. 31-52). In that way, many conservatives believed that environmentalists now replaced communists as the enemies Americans should fear. ${ }^{4}$

Other Carson detractors claimed that her arguments were not based on science, but on faith. They described environmentalism, as Carson and her followers envisioned it, as a pseudo-religion. "Green worshippers can keep their religion," snorted one critic of ecology, while another described it as a "new religion, a new paganism that worships trees and sacrifices people" (Dunlap, 2004, p. 5). Physician and novelist Michael Crichton (2003) called environmentalism "one of the most powerful religions in the Western World." In the spirit of Judeo-Christian beliefs, Crichton (2003) suggested, environmentalism begins with an Eden:

4 See also the jacket liner notes for the "green menace" quotation. 
A state of grace and unity with nature; there's a fall from grace into a state of pollution as a result of eating from the tree of knowledge, and as a result of our actions there is a judgment day coming for all of us. We are all energy sinners, doomed to die, unless we seek salvation.

In this environmental religion, salvation comes as "sustainability." Crichton dismissed this "Green" worldview as romantic nonsense. "People who live in nature," he assured his audience, "are not romantic at all” (Crichton, 2003).

With the election of George W. Bush, anti-environmental critics moved far beyond accusing Carson of bad science and misguided beliefs. They accused her of murder. An outraged blog writer claimed that around the world, a pandemic wreaked a terrible toll: a child died every 15 seconds; 3 million people succumbed each year; and from 1972 to 2003, 100 million people had been lost. "These deaths," the author fumed, "can be laid at the doorstep of author Rachel Carson" (Makson, 2003). How had Carson done this horrid deed? "Her 1962 book Silent Spring detailed the alleged 'dangers' of the pesticide DDT, which had practically eliminated malaria." Without that "cheap, safe, and effective" weapon to control insect-borne disease, "millions of people-mostly poor Africans-have died due to the environmentalist dogma propounded by Carson's book" (Makson, 2003).

Writing in the New York Times in April 2004, Tina Rosenberg (2004) made such claims credible: "DDT killed bald eagles because of its persistence in the environment. Silent Spring is now killing African children because of its persistence in the public mind." Crichton abandoned derision for moral outrage. "Banning DDT is one of the most disgraceful episodes in the Twentieth Century history of America," he commented. "We know better, and we did it anyway, and we let people around the world die and we don't give a damn" (Crichton, 2003). Crichton pursued his crusade in his footnote-studded 2004 novel, State of Fear. "Banning DDT killed more people than Hitler," his hero charges. "And the environmental movement pushed hard for it" (Crichton, 2004, p. 487).

Leading the political charge was Republican Senator Tom Coburn of Oklahoma. Coburn blocked bills to honor Carson and to name a Pennsylvania post office for her. His website linked visitors to "Rachel Was Wrong," sponsored by the Competitive Enterprise Institute (a think tank for climate change deniers). Beside grim pictures of malaria victims, the Competitive Enterprise Institute claimed, "millions of people around the world suffer the painful and often deadly effects of malaria because one person sounded a false alarm. That person is Rachel Carson" (Rachel Carson's dangerous legacy, 2007).

These latter-day Carson critics marshaled some disturbing evidence. According to Rosenberg (2004), health officials estimated that malaria killed 2 million people every year, with the largest proportion being children under five living in Africa. Until the recent explosion of the AIDS epidemic, malaria was Africa's leading killer, 
taking the lives of one in 20 children and leaving countless millions of others brain damaged. Worldwide, health officials estimated 300-500 million people contracted malaria each year. Beyond the loss of life and untold suffering it caused, malaria shrank the economies of some of the world's poorest countries by some 20 percent over 15 years (Rosenberg, 2004). What so disturbed Crichton, Rosenberg, and others was that a cheap and effective way to curb the pandemic existed. The solution, Rosenberg asserted, "lasts twice as long as the alternatives. It repels mosquitoes in addition to killing them, which delays the onset of pesticide-resistance. It costs a quarter as much as the next cheapest insecticide" (2004, p. 83). The answer, Rosenberg assured her readers, was DDT. Semi-annual spraying of the interior of huts in South Africa with DDT greatly reduced malaria and the related health costs.

Even though the EPA banned DDT in 1972, it did not ban its manufacture, nor did international law prevent other countries from using it. What then stopped the poor nations of the world from spraying DDT to curb the malarial scourge? The simple answer offered by these critics was "Rachel Carson." The prejudice against DDT that Carson aroused in Silent Spring made it difficult for health officials to press for its use. Moreover, alongside the US, most other developed nations banned DDT as well. By 2005, this situation had put the developing world in a double bind. The health organizations assisting the poorer countries in the battle against malaria received their funding from the wealthier nations in which prejudice against DDT was strongest. One foreign aid administrator admitted that her agency would not finance DDT because "you'd have to explain to everyone why this is really OK and safe every time you do it, so you go with the alternative that everyone is comfortable with" (Rosenberg, 2004, p. 83).

This case would offer a withering indictment of Carson and "her coterie of admirers," if it held up to close examination. Is it true, for example, that 300-500 million people a year become ill with malaria? That number seems unreasonably high. If it were accurate then within as few as 14 years, malaria would infect all the world's 8 billion people. Clearly, that is not the case. What then does this number actually mean? Not that 300-500 million people contract malaria each year, but that 300-500 million people show symptoms of the disease. Many of those "incidence[s] of clinical disease episodes" occurred in people who had been infected for many years, and so were not, in fact, new cases (Hamilton Lytle, 2007a, p. 223).

What then of the 1.1-2 million people who die from malaria, most of them African children under the age of five? Would the wider use of DDT reduce this level of mortality? Surely, such a number would justify a worldwide effort to contain the disease, even if that meant a significant increase in the use of DDT. Looking at statistics collected by the World Health Organization (WHO) offers a clearer picture of the death rate of African children under five (Weir, 2007). As frightening as malaria might be, it ranked only fourth as a cause of infant mortality. Respiratory infections and diarrhea claimed over twice as many lives as malaria, while neonatal 
conditions such as preterm birth and low birth weight killed as many as 10.6 million infants annually. AIDS has been another deadly killer, but its victims die less often in infancy. Such comparisons suggest that if those who condemned Carson and Silent Spring truly cared about the children of Africa, they might move beyond their preoccupation with malaria and DDT and propose alternative solutions to the AIDS crisis, water pollution, malnutrition, and infectious diseases, which are the continent's greatest killers. However, unlike DDT for malaria, there is no easy fix for these serious issues afflicting Africa. Addressing them requires a more comprehensive plan than DDT's advocates have supported.

As Kristen Weir noted in a 2007 Salon article, "Overseas, DDT was being phased out of the fight against malaria, but Carson and budding environmentalists were not the reason." A WHO scientist explained that the global eradication program "oversold the possibility of eradication" and the US withdrew its financial support. By 1969, the WHO had officially abandoned the eradication effort. A 2001 article explained, "Despite the successes of the WHO eradication campaign in many parts of the world following the Second World War, most of Africa was regarded as a lost cause, and in practice the eradication of malaria in Africa was never attempted" (Weir, 2007). The WHO, because it could never afford a massive insecticidespraying program and at the same time help countries to build up basic health services, chose the latter. Better public health services helped to improve childhood mortality in Africa, but malaria programs faltered.

Malaria is a complex disease caused by a parasite with a complicated life cycle. "For malaria control, you need to have a really good understanding of mosquitoes, the malaria parasite and human behavior," observed Richard Tren, chair of the board of Africa Fighting Malaria, an advocacy group that champions DDT (Weir, 2007). He believed that many health programs were ill-equipped to handle that complexity. By contrast, malaria researchers at the Johns Hopkins Bloomberg School of Public Health stressed that aid organizations were pro-medicine not anti-DDT. Through the 1970s and 1980s, most countries, on the advice of the WHO, "changed their approach to malaria control from insecticide treatment to treating people with chloroquine"-which kills the parasites that cause malaria- "because that was a way they could impact the mortality of the disease" (Weir, 2007). According to research, malaria caused 18 percent of deaths in Africa before 1960 and 12 percent of deaths between 1960 and 1989. In other words, malaria-related mortality decreased after treatment shifted from insecticides to medicine. As for the DDT debate Crichton and others promoted, well-regarded researcher May Berenbaum said, "it's all emotional and not rational" (Weir, 2007). "Carson's point wasn't that DDT was evil, it was that if you put all your eggs in one basket, that basket's going to break" (Weir, 2007). 
Equally problematic for DDT advocates, many agricultural producers in the developing world also supported the DDT ban. The US and Europe generally barred any imported crops containing traces of the pesticide. The chemical companies that once attacked Carson and vigorously defended DDT also ceased doing so, although this was because DDT was no longer under patent, which meant that any company could now manufacture it. Chemical companies thus found it more profitable to sell other insecticides. As Janet Hemingway of the Liverpool School of Tropical Medicine observed, "Clearly, they'd like to see DDT banned-it cuts into their markets" (Rosenberg, 2004).

Another question worth asking in response to a recurring argument among Carson's critics is, is it true that DDT poses no significant risk to humans? One advocate of DDT claimed, "if you use DDT properly, it has a record of safety and effectiveness for humans that is really unmatched" (Hamilton Lytle, 2007a, p. 226). By demonstrating that DDT is in fact harmless, critics enhanced their claim that Carson's work was based on bad science, unwarranted assumptions, and "fear-mongering." Yet, two highly respected researchers who studied the impact of DDT exposure on preterm births and the length of time mothers nursed estimated from their data what might happen if Africans resorted to wider indoor spraying (Hamilton Lytle, 2007b). They found, for example, that among women in Mexico and North Carolina, those with higher concentrations of DDT nursed for shorter periods. In Africa, where food is scarce, mothers breastfeed for an average of 18 months. If lactation there fell to the levels found in Mexico and North Carolina, infant mortality might reach a level surpassing any benefit from spraying DDT. Thus, those who have spoken with such moral passion about the virtues of DDT may well have been recommending a cure that was more dangerous than the malaria they were trying to eradicate. ${ }^{5}$

In a 1963 televised debate with Carson, a scientist from the American Cyanamid Corporation argued in defense of the chemical industry that "man is steadily learning to control nature." To that, Carson replied that the big challenge was to prove "our maturity and our mastery, not of nature, but of ourselves." Maturity required thinking of "ourselves as only a tiny part of a vast and incredible universe" (CBS Reports, 1963). With more humility, humans might better ensure the future for themselves and their fellow species. As environmental historian Donald Worster (1994) concluded, this idea became "the central creed of the ecology movement: a vision of the unity of life, as taught by science, and a moral ideal of living cooperatively with all members of the natural community" (pp. 348-351). The idea of living in harmony with nature contradicted the central assumption of a generation of scientists who preached the conquest of nature, whether through manipulation of the atom, synthetic materials, or deadly pesticides. 
In another way, Carson challenged the authority of corporate and scientific elites. If, as she charged, the dangers of pesticides were real, through silence or, even worse, deceptive claims on this issue, science and industry had abdicated their responsibility. "This is an era of specialists, each of whom sees his own problem and is unaware of or intolerant of the larger frame into which it fits," she observed (Carson, 1962, pp. 12-13). Carson wanted the future to be decided by an informed public with a holistic view of nature, rather than self-serving businesses or narrowly trained specialists. As she argued:

It is the public that is being asked to assume the risks that the insect controllers calculate. The public must decide whether it wishes to continue on the present road, and it can do so only when in full possession of the facts. In the words of Jean Rostand, "The obligation to endure gives us the right to know." (Carson, 1962, pp. 12-13)

In essence, Carson's determination to have the public rather than the experts make such vital choices required a radical transformation in public policy. She advocated nothing less than "Power to the People." That ideal of participatory democracy inspired much of the political dissent during the 1960s. In Silent Spring, Rachel Carson challenged Americans to gain control of their future. If that was subversion, then long live the people.

Despite her critics, Carson would have been among the first to support limited applications of DDT in order to save lives. In Silent Spring, she never spoke against responsible use of pesticides. Rather, she urged that the methods of insect control "be such that they do not destroy us along with the insects" (Carson, 1962, p. 9). What she did condemn were uncritical and often untested claims that these chemicals were harmless to humans and other living things. She further decried the anthropocentric point of view that saw humans as somehow separate from and not responsible for their impact on nature. For Carson, life was a wondrous mystery to behold and she asked her fellow beings to be aware "that we are dealing with lifeliving populations and all their pressures and counter-pressures, their surges and recessions" (Carson, 1962, p. 296).

Perhaps she was not a saint, but she was far less a sinner than those who condemn her.

\section{References}

Carson, R. (1962). Silent spring. Boston, MA: Houghton Mifflin.

CBS Reports. (1963, April 3). The silent spring of Rachel Carson [transcript]. CBS Reports. 
Crichton, M. (2003, September 15). The greatest challenge facing mankind: Remarks to the Commonwealth Club of San Francisco. www.cs.cmu.edu/ kw/ crichton.html

Crichton, M. (2004). State of Fear. New York, NY: HarperCollins Publishers.

Dunlap, T. R. (2004). Faith in nature: Environmentalism as religious quest. Seattle, WA: University of Washington Press.

Gotlieb, R. (1993). Forcing the spring: The transformation of the American environmental movement. Washington, DC: Island Press.

Hacker, J., \& Pierson, P. (2005). Off center: The republican revolt and the erosion of American democracy. New Haven, CT: Yale University Press.

Hamilton Lytle, M. (2007a). The gentle subversive: Rachel Carson, Silent Spring, and the rise of the environmental movement. New York, NY: Oxford University Press.

Hamilton Lytle, M. (2007b). Rachel Carson: Saint or Sinner. Oxford University Press Blog. Retrieved from blog.oup.com/2007/03/rachel_carson_s/

Helvarg, D. (1994). The war against the greens: The "wise-use" movement, the new right and the browning of America. San Francisco, CA: Sierra Club.

Howarth, W. (2005). Turning the tide: How Rachel Carson became a woman of letters. American Scholar, 74(3), pp. 42-52.

Karaim, R. (2005). Not so fast with the DDT: Rachel Carson's warnings still apply. The American Scholar, 74(3), 53-59.

Lear, L. (2009). Rachel Carson: Witness for nature. New York, NY: Henry Holt.

Makson, L. (2003, July 31). Rachel Carson's ecological genocide. frontpagemag.com

Rachel Carson's dangerous legacy. (2007, March 1). SAFEChemicalPolicy.org. Retrieved from www.safechemicalpolicy.org/rachel-was-wrong/

Rosenberg, T. (2004, April 11). What the world needs now is DDT. New York Times, Sunday Magazine.

Rubin, C. (1994). The green crusade: Rethinking the roots of environmentalism. New York, NY: Rowman \& Littlefield.

Shabecoff, P. (1993). A fierce green fire: The American environmental movement. New York, NY: Hill and Wang.

Souder, W. (2013). On a farther shore: The life and legacy of Rachel Carson, author of Silent Spring. New York, NY: Crown Books. 
Human Ecology Review, Volume 23, Number 2, 2017

Weir, K. (2007, June 29). Carson birthday bashing. Salon. Retrieved from www.salon.com/2007/06/29/rachel_carson/

Worster, D. (1994). Nature's economy: A history of ecological ideas (2nd ed.). New York, NY: Cambridge University Press. 
This text is taken from Human Ecology Review, Volume 23, Number 2, 2017, published 2017 by ANU Press, The Australian National University, Canberra, Australia.

dx.doi.org/10.22459/HER.23.02.2017.06 